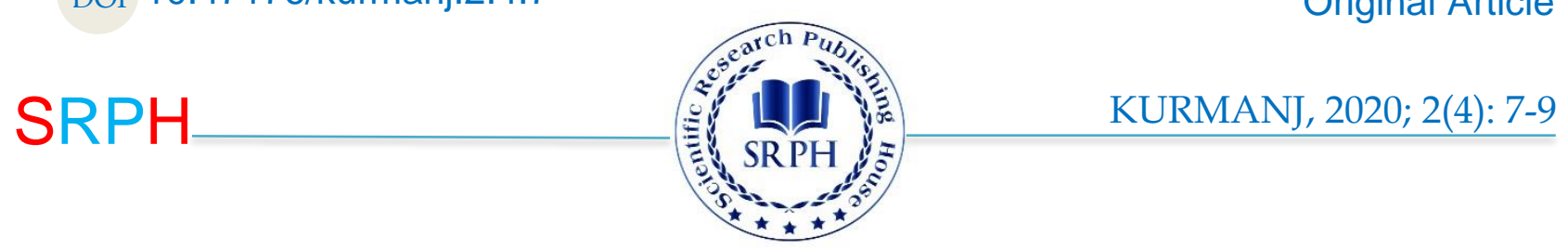

\title{
The Impact of Source Text Culture on the Quality of Translation
}

\author{
Hamed Ghaemi* \\ Bahar Institute of Higher Education, \\ Mashhad, Iran.

\section{*Corresponding Author: \\ $\rtimes$ ghaemiacademy@gmail.com}

Received: 15 September, 2020

Accepted: 30 October, 2020

Published: 15 November, 2020

\begin{abstract}
The present article reports a study carried out to investigate whether or not awareness of ST culture has any impact on the translation quality of translator trainees. 20 Iranian graduated from English translation took part in this study. They were divided into two groups, one experimental and one control groups. After homogenizing the participants through a TOEFL test, a translation pre-test was given to them and then cultural backgrounds of ST were taught to the experimental group who were later required to use the taught material in their classroom translation practice during one academic semester. The control groups were run traditionally as widely practiced in Iranian graduated translation classes. A translation post-test was given to all the groups at the end of the semester. The statistical results demonstrate a significant difference between the pre- and posttests in the experimental group as compared with the control group.
\end{abstract}

Keywords: Translation, Source text, Culture, Quality of translation

\section{Introduction}

Since the creation of language, translation began to come into being. Though translation has a long history, in the beginning, people simply translated just for communication. At that time there was no professional translator but after the industrial revolution, increasing imports and exports and also increasing exchanges among different language areas, translation was playing a more and more important role in communication. So the need for professional translators created. Some believe that translation is an act of reproducing words, phrases, sentences and so on in target language. But some other considers it as a process of transferring the source culture into target language. Little by little translation took various aspects. Cultural approach as an aspect was investigated by linguists.

According to Hatim and Mason [1], the social context in translating a text is probably a more important variable than its genre. In fact the act of translating takes place in the socio-cultural context. Eugene Nida [2] saw translation as one of the major means of constructing representations of other cultures. He clearly recognized that translation always involves both different languages and different cultures simply because the two cannot be neatly separated. Language is culturally embedded: it serves to express and shape cultural reality, and the meanings of linguistic units can only be understood when considered together with the cultural contexts in which they arise, and in which they are used. Translations are seen as cultural facts, as 'facts of the culture which hosts them' [3], and translation activities are both norm-governed and seen as having cultural significance. Bassnett and Lefevere attached great importance to the role of culture in translation, the social background, and the influence that cultural tradition imposed on translation [4]. According to Nida, "the relationship between receptor and message should be substantially the same as that which existed between the original receptors and the message" [5]. Now the question is that how ST culture can influence the quality of translation in Iranian graduated students majoring at English translation?

Several researches have done by scholars on the issue of culture and translation. However sometimes it seems impossible to express the exact source text message in TT which may consist of for example some taboo words. In addition what this paper will see is the usage of cultural approach in translation.

Written by the author of the world's best known model of translation quality assessment, Juliane House, this book provides an overview of relevant contemporary interdisciplinary research on translation, intercultural communication and globalization, and corpus and psycho- and neuro-linguistic studies. House 
acknowledges the importance of the socio-cultural and situational contexts in which texts are embedded, and which need to be analyzed when they are transferred through space and time in acts of translation, at the same time highlighting the linguistic nature of translation [6].

In her article on translator training programs, Christina Schäffner tends to operate with a more traditional concept which involves transfer across languages and cultures, although she cannot claim that all members of staff teaching on one and the same program also share the same understanding of what translation means [7].

\section{Design}

An experimental study showing the impact of source text culture on the quality of translation has been done.

\section{Subject}

Out of 100 Iranian between the ages of 20 to 30 graduated from English translation at Imam Reza International University 20 were randomly selected.

\section{Instruments}

The students have been taken tests about whether they implied the source text culture in translation or not.

\section{Procedure}

The examinees had been taken a translation test in an English institution. The test contained a number of translation tasks to see how they transferred the source text culture in the process of translation. In fact they were provided with some information about the ST culture and then they did the translation. As time estimated the test took about 90 minutes to translate the texts. Also the statistical analyses obtained from SPSS (Statistical Package for the Social Science).

\section{Results and Discussion}

In order to show there is no significance between the two of experimental and control group, a pre-test was conducted. Tables 1 show the results of the independence sample t-test for pre-test. According to the table (1-1) both experimental and control group with 10 participants for each of them took the mean of 13.750 and 13.625 which mean that the two groups are roughly identical. Also as table (1-2) showed t (18) $=1.011, \mathrm{P}<0.05$. The results showed that $\mathrm{p}$-value 0.5 , in addition the critical t-value for $\mathrm{df}=18$ is 1.101 , according to the results, the critical t-value is 1.011 that is below the required critical t-value.

Table 1

\begin{tabular}{lcccc} 
Pre-test. & & & & \\
\hline Group & $\mathbf{N}$ & Mean & Std. Deviation & Std. Error Mean \\
\hline Experimental & 10 & 13.7500 & 1.28174 & .45316 \\
Control & 10 & 13.6250 & 1.68502 & .59574 \\
\hline
\end{tabular}

Table 2

Independent Samples Test (post-test).

\begin{tabular}{lccccc}
\hline & \multicolumn{2}{c}{$\begin{array}{c}\text { Levene's Test for } \\
\text { Equality of Variances }\end{array}$} & \multicolumn{3}{c}{$\begin{array}{c}\text { t-test for } \\
\text { Equality of Means }\end{array}$} \\
\cline { 2 - 6 } & $\mathrm{F}$ & Sig. & $\mathbf{t}$ & $\mathbf{d f}$ & Sig. (2-tailed) \\
\hline Equal variances assumed & .465 & .504 & 1.011 & 18 & .325 \\
Equal variances not assumed & & & 1.011 & 17.707 & .326 \\
\hline
\end{tabular}

In order to show there is significant difference between the experimental and control group a post-test was conducted. According to table (2-1), the mean score of participants in experimental group is 17.5 while the mean score of control one is 14.6. It shows that the group who received the treatment during the process of translation was more successful in the test than those who did not. As the results of tables showed we can see that being familiar with the ST culture influences the way in which individuals translate the texts and in fact it improve the quality of the translation $(\mathrm{p}=0.1>0.05)$. According to the results of table $(2-2)$, the critical $t$-value is 3.597 that is above the required $t-$ value so, the independent samples t-test proved that there is significant difference between two groups.

Table 3

Post-test.

\begin{tabular}{lcccc}
\hline Group & $\mathbf{N}$ & Mean & Std. Deviation & Std. Error Mean \\
\hline Experimental & 10 & 17.5000 & 1.41421 & .50000 \\
Control & 10 & 14.6520 & 1.68502 & .59574 \\
\hline
\end{tabular}


Table 4

Independent Samples Test (post-test).

\begin{tabular}{lccccc}
\hline & \multicolumn{2}{c}{$\begin{array}{c}\text { Levene's Test for } \\
\text { Equality of Variances }\end{array}$} & \multicolumn{3}{c}{$\begin{array}{c}\text { t-test for } \\
\text { Equality of Means }\end{array}$} \\
\cline { 2 - 6 } & F & Sig. & t & df & Sig. (2-tailed) \\
\hline Equal variances assumed & 2.469 & .134 & 3.597 & 18 & .002 \\
Equal variances not assumed & & & 3.597 & 13.395 & .003 \\
\hline
\end{tabular}

\section{Conclusion}

The aim of this article was to investigate the impact of ST culture on the quality of translation. It was revealed that the score of the students in the experimental group who were provided with ST culture before the process of translating did better in the test than those who didn't. The findings of this study also shows that our null hypothesis is rejected which mean there is difference between groups.

\section{References}

1. Hatim B, Mason I. Discourse and the translator. Longman: Longman Group Limited. 1990.
2. Nida Eugene. Toward a science of translation. Leiden: Brill. 1964.

3. Toury Gideon. Descriptive translation studies and beyond. Revised edition. Amsterdam: Benjamins. 2012.

4. Bassnett S, Lefevere A. Translation, history and culture. London: Printer Publishers. 1990.

5. Nida EA. Towards a science of translating: with special reference to principles and procedures involved in Bible translating. Leiden: Brill. 1964.

6. Juliane House. A model for translation quality assessment. Revised edition. 2012.

7. Christina Schäffne. The role of discourse analysis for translation and translator training. Multilingual Matters, Cleve don. 2002.

\section{KURMANJ}

Copyright: () 2020 The Author(s); This is an open-access article distributed under the terms of the Creative Commons Attribution License (http://creativecommons.org/licenses/by/4.0), which permits unrestricted use, distribution, and reproduction in any medium, provided the original work is properly cited.

Citation: Ghaemi H. The Impact of Source Text Culture on the Quality of Translation. KURMANJ, 2020; 2(4): 7-9.

https://doi.org/10.47176/kurmanj.2.4.7 